\title{
"Environmental accounting as perspective for hotels of Aqaba special economic zone authority (ASEZA)"
}

\begin{tabular}{|c|c|}
\hline AUTHORS & 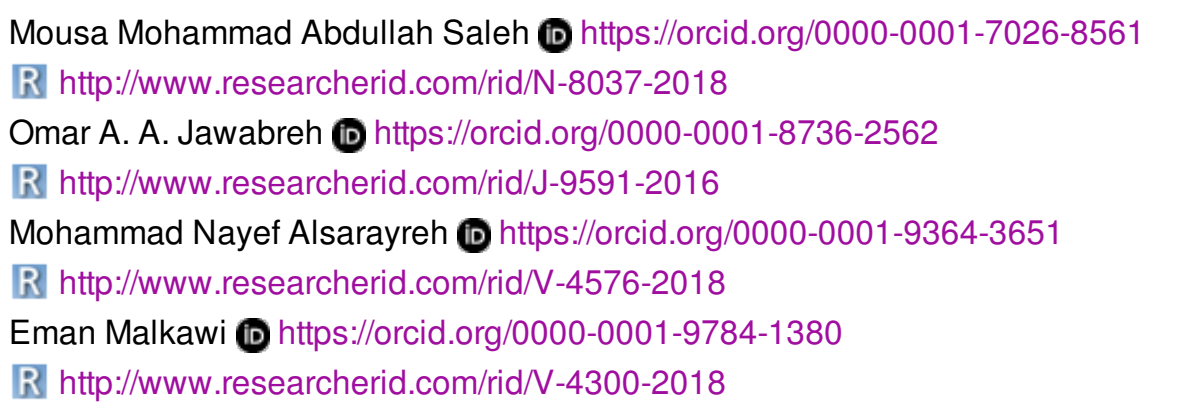 \\
\hline ARTICLE INFO & $\begin{array}{l}\text { Mousa Mohammad Abdullah Saleh, Omar A. A. Jawabreh, Mohammad Nayef } \\
\text { Alsarayreh and Eman Malkawi (2018). Environmental accounting as perspective } \\
\text { for hotels of Aqaba special economic zone authority (ASEZA) . Problems and } \\
\text { Perspectives in Management, 16(4), 169-185. doi:10.21511/ppm.16(4).2018.15 }\end{array}$ \\
\hline DOI & http://dx.doi.org/10.21511/ppm.16(4).2018.15 \\
\hline RELEASED ON & Thursday, 08 November 2018 \\
\hline RECEIVED ON & Monday, 25 June 2018 \\
\hline ACCEPTED ON & Thursday, 11 October 2018 \\
\hline LICENSE & \begin{tabular}{|l}
$(\mathrm{oc}) \mathrm{EY}$ \\
This work is licensed under a Creative Commons Attribution 4.0 International \\
License
\end{tabular} \\
\hline JOURNAL & "Problems and Perspectives in Management" \\
\hline ISSN PRINT & $1727-7051$ \\
\hline ISSN ONLINE & $1810-5467$ \\
\hline PUBLISHER & LLC "Consulting Publishing Company "Business Perspectives" \\
\hline FOUNDER & LLC "Consulting Publishing Company "Business Perspectives" \\
\hline $0^{\circ}$ & $\begin{array}{l}\text { 三ニ二 } \\
\text { 三ニ }\end{array}$ \\
\hline NUMBER OF REFERENCES & NUMBER OF FIGURES \\
\hline 45 & 11 \\
\hline
\end{tabular}

(c) The author(s) 2023. This publication is an open access article. 


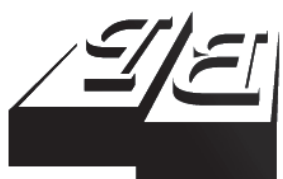

BUSINESS PERSPECTIVES

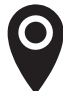

LLC "CPC "Business Perspectives" Hryhorii Skovoroda lane, 10, Sumy, 40022, Ukraine

www.businessperspectives.org

Received on: $25^{\text {th }}$ of June, 2018 Accepted on: $11^{\text {th }}$ of October, 2018

(C) Mousa Mohammad Abdullah Saleh, Omar A. A Jawabreh Mohammad Nayef Alsarayreh, Eman Malkawi, 2018

Mousa Mohammad Abdullah Saleh, Ph.D., Assistant Professor of Accounting, Department of Financial and Administrative Sciences, AlBalqa Applied University, Jordan.

Omar A. A. Jawabreh, Ph.D., Assistant Professor of Hospitality, Hotel management, Department of Hotel Management, Faculty of Tourism and Hotel, The University of Jordan, Jordan.

Mohammad Nayef Alsarayreh, Ph.D., Associate Professor, Al-Balqa Applied University, Jordan.

Eman Malkawi, Lecturer of Business, Business Department, Faculty of Business and Finance, The University of Jordan, Jordan.

\section{(ㄷ)(i)}

This is an Open Access article, distributed under the terms of the Creative Commons Attribution 4.0 International license, which permits unrestricted re-use, distribution, and reproduction in any medium, provided the original work is properly cited.
Mousa Mohammad Abdullah Saleh (Jordan), Omar A. A Jawabreh (Jordan),

Mohammad Nayef Alsarayreh (Jordan), Eman Malkawi (Jordan)

ENVIRONMENTAL

ACCOUNTING AS PERSPECTIVE

FOR HOTELS OF AQABA

SPECIAL ECONOMIC ZONE AUTHORITY (ASEZA)

\section{Abstract}

This study aims at pointing out and explaining the major factors that can help in implementing environmental accounting in the hotels of Aqaba Special Economic Zone, the study population is going to be the classified and rated hotels of the Aqaba Special Economic Zone Authority, which is 33 hotels in total. This study will basically focus on two tools for gathering the data and information required for achieving the objectives of the study, the financial reports published by the investment department of Aqaba and the questionnaire. The study shows that the hotels in Aqaba Special Economic Zone Authority face difficulties and obstacles in the implementation of environmental accounting because of factors related to legislation, level of awareness about environmental accounting, factors related to the hotels and the qualification of human resource.

\section{Keywords}

\section{JEL Classification}

\section{Economic Zone Authority, incentives}

\section{INTRODUCTION}

The environmental accounting plays a number of important roles, which made this study to demonstrate the scope of implementing environmental accounting in the hotels of Aqaba Special Economic Zone, and this region was selected for this study because of its financial importance, one of being the favorite destinations for tourists and the special tax exemptions that companies and investment institution enjoy in this region.

Environmental accounting (in theory and practice) observes a comprehensive image of the foremost research issues within the field, supported by the experience of many countries with the introduction of integrated environmental and economic statistics, as well as physical accounting ways for material flows and spatial accounting for land use. Theoretical problems regarding the valuation of environmental products and the concept of sustainability are also mentioned.

The topics of environment and the conservation of environment are now being included in many different branches of science. Accounting is one of the fields of science that have taken care of the environment recently, within social accounting, and attention to the environment is a major demand in many countries, especially developed ones. Environmental accounting, which is important in providing data on environmental costs to help the administration of the enterprise in 
the planning, monitoring and control of the performance of enterprises, has emerged from this attention. In some developed countries such as Britain, we find that some British universities have an independent major called environmental accounting (Anjali Vachhani, 2014).

Accordiong to Ribeiro and Aibar-Guzman (2010), the aim of this paper is to look at the extent to what Jordanian native entities have enforced a collection of environmental accounting practices and to investigate some potential crucial factors of their use.

A set of tools that helps managers to identify the environmental effects of their business is called environmental management accounting. Burrit (2005) indicated that the field of environmental accounting that has no systematic research is the relationship between environmental management accounting and environmental risk. Moreover, Ribeiro and Monteiro (2009) stated that there are not too many studies about hotel environmental accounting, which leads to a poor competitive advantage.

Noemi Rossi and Raffaele Trequattrini (2010). Introducing and developing environmental reports within the Lazio region between national guidelines and pilot experiences of native governments in the European countries.

Many governmental and non-governmental organizations have shown great interest in environmental accounting, because it plays an effective role in showing the environmental impact of the establishment (enterprise) through financial reports. Part of interest is clear in the presentation of certain environmental accounting standards that contribute to the organization's financial statements (Lulu, 2016; Abu Rumman et al., 2013). The World Bank has obliged state governments to include environmental accounting information into their national calculations.

Environmental accounting and environmental accounting disclosure are considered to be a growing issue in recent decades because of the societal pressures resulting from increased environmental awareness among individuals and related organizations. Environmental reports issued by companies with industries affecting the environment have been of great interest to official and non-official bodies. It can be said that environmental accounting is a major branch of accounting that contributes to the preservation of the environment by identifying the environmental costs incurred by the establishment in order to do so and, therefore, issuing financial statements that determine the outcome of the establishment's business and its financial position, taking into consideration the environmental impact of the establishment and the contribution to the preservation of the environment.

Accounting is a wide, integrated, and inseparable environmental system, which is constantly interacting with and adapting to the changes that occur. From this perspective, as hotels are an integral part of the environment that affects and is influenced by the environmental changes occurring around it, the accounting system must have the necessary flexibility to adapt to the changes that may occur (Jumaa, 2017).

As a result of the absence of standards, instructions and legislations that compel enterprises to disclose environmental accounting data, this has led to a discrepancy in the scope and in the importance of this accounting information with significant financial environmental impact and also led to a contrast between the reasons for not disclosing that environmental accounting information. Hence, this study is used to identify the factors affecting the non-application of environmental accounting and the lack of disclosure of environmental accounting data within general major sectors such as the hotels sector (Sciulli, 2010).

This study aims at pointing out and explaining the major factors that can help in implementing environmental accounting in the hotels of Aqaba Special Economic Zone. 


\section{LITERATURE REVIEW}

The results of the present study agreed with several studies like Hanan (2014), Saleh (2015), Al-Hayek (2013) that the management and accountants lack awareness about the application of environmental accounting and environmental auditing and not doing it properly, although they have adequate knowledge about the requirements of environmental disclosure, internal environmental auditing, and the obstacles that prevent application. Also, the studies mentioned above are consistent about that it is necessary for the competent authorities to enact the required environmental laws and legislation, as well as to issue accounting standards required for the application of environmental accounting and environmental auditing, and the need to teach accounting and environmental auditing in Jordanian universities.

Lulu (2016) has identified the environmental awareness of senior management in industrial companies through a set of questions directed at corporate management aimed at identifying the company's environmentally friendly products and whether the company is working on finding solutions suitable for reducing the environmental pollution problem, and whether the company reports on the environmental performance to the credit granting entities.

The study also examined the extent to which senior management recognizes the advantages and benefits of applying environmental cost accounting by examining the impact of applying environmental cost accounting on the image of the organization, achieving competitive advantage, achieving customer requirements and reducing the cost of production.

The study by Salen (2015) also has identified the environmental awareness of the management through the integration of the awareness of the administration of the organization and the extent of their commitment to environmental legislation and laws. In order to achieve this, a series of questions were directed to both the employees of the organization and the investors in the same organization.

Al-Zaher (2011) dealt with one of the most important obstacles that may prevent many hotels from applying environmental accounting system that was dealt with in the current study. There is an agreement between the two studies in terms of obstacles of ap- plying environmental accounting disclosure, most notably the lack of educational programs related to environmental accounting. This was also mentioned in many other studies such as Hanik (2014), Saleh (2015), and Al-Hayek (2013). These studies showed that there is a lack of awareness of the importance of applying environmental accounting and environmental accounting disclosure. There is also an agreement between the study of Al-Zaher (2011) and the current study on the absence of an accounting system for environmental disclosure, since most accounting programs available in hotels and various establishments do not address environmental accounting treatments or even accounting disclosure requirements. Hanan (2014), Al-Ashqar (2011) and Abdel Aziz (2016) have stressed the importance of necessity of developing an environmental accounting system that assists management in making various decisions and increasing environmental awareness at all administrative levels in the organization.

Al Taher (2010) examined a new dimension of the impact on the application of the system of environmental accounting and environmental accounting disclosure, which is the users of the financial statements, since these users may constitute a strong and influential element towards the application of the environmental accounting system. This agrees with what the present study concludes. The main recommendations of the two studies are the need to increase the environmental awareness of the users of the financial statements in order to form a pressure force on the various organizations, especially hotels, to carry out their duties towards the environment and thus to create an effective environmental accounting system. In the opinion of the researcher, the financial statements may be regarded as a tool of pressure on the management of industrial organizations to carry out their duties towards the environment and to activate and implement the system of environmental accounting.

Al-Sha'ar, Zalloum, and Omar (2014) concluded that there is no impact of environmental accounting disclosure on financial performance. This means that there are no incentives to encourage the hotels and organizations to apply environmental accounting system and environmental accounting disclosure. The previous study concluded that the owners of organizations tend to produce a product with certain specifications without paying attention to the 
environmental aspect of this product. The expected investment in activities related to environmental resource development may generate low returns, because spending in this area would increase operating costs without achieving a return and this negatively affects the financial performance. The current study suggests that the main causes of the hotels in the lack of interest in the application and an effective accounting system lie in the following points:

- the need to provide adequate knowledge and information for the managers and accountants of hotels and to clarify the importance of the application of environmental accounting system and its role in reducing operational costs and thus increasing profits Abdel-Lawi (2015), Hamad (2014), Al Dosaree (2011), not as some hotel managers think that it will reduce the profits due to increasing costs;

- providing incentives and governmental facilities to encourage different hotels and organizations to provide the environmental product and service in a way that competes with the rest of the products Hamad (2014);

- providing appropriate awareness about the importance of investment and the demand for and the favor of the environmental product in comparison with other products.

Al Dosaree (2011) highlighted the importance of environmental accounting disclosure in enhancing competitiveness among enterprises by providing the best product and service, and enhancing the ability of enterprises to cope with challenges in light of industrial and economic expansion. The current study highlighted the importance of this variable, as well as it provided appropriate solutions to enhance competitiveness through the essential incentives and directing investment towards environmental product and service.

Abedel-Aziz study (2016) recommended that the state should stimulate industrial companies that disclose social responsibility costs such as exempting them from taxes or other facilities in return for their social contribution, and recommended that the state adopts positive attitudes and practices towards industrial companies that bear social responsibility.
Al-Farah and Al-Hindawi study (2011) recommended that the governmental bodies supervising the performance of companies should perform their responsibilities towards society and environment. The method of encouragement and intimidation should be followed, such as granting an annual award to the best Jordanian company that applied social responsibility standards and granting it privileges to encourage it to carry out its social and environmental responsibilities to the fullest.

The study of Abdel-Lawi (2015) recommended that the concerned bodies should support the establishments and show the importance of social and environmental responsibility and the need to direct tax exemptions and provide facilities and subsidies to institutions that achieve efficiency in social performance towards employees, environment and society.

Saleh (2015) concluded that companies that do not practice environmental disclosure should be urged to apply disclosure standards, as this would increase their competitiveness. Hamad (2014) also found that measuring and disclosing environmental costs positively affects the improvement of environmental performance through its impact on increasing production and sales, reducing environmental risks and increasing the occupational safety of workers.

The study of Lu and Abeysekara (2014) concluded that there is a relationship between corporate and environmental accounting disclosure of companies and company size, profitability and industry type.

Al Dosaree study (2011) presented different results from the current study by addressing some of the factors related to the enterprise. It concluded that environmental accounting disclosure is not affected by the size of the company or its capital, in contrast to the findings of the present study and the study of Burgwal and Vieira (2014). The present study coincided with the study of Burgwal and Vieira (2014) that the application of environmental accounting is influenced by factors related to the company. The size of the company's assets and the nature of the company's activities are considered the main factors influencing the application of environmental accounting and environmental accounting disclosure. The current study also 
found some additional factors that directly affect the application of environmental accounting, such as the size of the production, the size of the capital and the geographic location of the enterprise.

\section{PROBLEM OF THE STUDY}

The environmental organizations started to take action against tourism projects by asking companies to show their contribution in fighting pollution and (or) causing it, and keep a dedicated budget in their accounts for combating pollution or show this contribution in their accounts.

This problem can be better understood through these questions:

- Does the Jordanian judiciary system contribute to implementing environmental accounting and its different procedures?

- Does the level of awareness about environmental accounting among the corporate sector helps in performing the procedures of environmental accounting?

- Do the different factors related to hotels (location, capital, turnover, the kind of business that the hotel performs) help in implementing the environmental accounting?

- Is the level of incentives given to the companies encouraging them to perform the procedures of environmental accounting?

- Is the implementation process of environmental accounting in a company affected by the qualification and quality of its human resource?

\section{OBJECTIVE OF THE STUDY}

This study aims at pointing out and explaining the major factors that can help in implementing environmental accounting in the hotels of Aqaba Special Economic Zone, and this can be achieved through identifying the following legal obstacles that are preventing the implementation of environmental accounting: knowing the impact of companies' awareness about the importance of environmental accounting on carrying out its procedures;

- identifying the impact of different factors related to hotels (location, capital, turnover, the kind of business that the hotel performs) on the procedure of implementing the environmental accounting;

- indicating the impact of the level of environmental accounting related incentives on its implementation;

- indicating the impact of qualified human resource on the implementation of environmental accounting and Finding recommendations that would help in the implementation of environmental accounting.

\section{THE IMPORTANCE OF THIS STUDY}

The importance of this study is evident in the following points:

1) identification of the factors that could contribute to the implementation of environmental economy system, which consequently can show the accounting records of the amount with which the hotels contributed to limiting the environmental pollution;

2) the most fruitful outcome of environmental accounting is that it'll help in distinguishing between production cost and expenditure and the cost incurred because of social and environmental reasons, this assures high level of accuracy in accounting analysis and the financial percentages used in the decision making of a particular hotel and show more realistic results of its activities;

3) this study will help in highlighting the factors, which are hindering the implementation of environmental accounting in Aqaba Special Economic Zone, and this will help the companies that are willing to implement the environmental accounting system in tackling such factors and this can be the starting point so that every other region in Jordan can start implementing the system. 


\section{RESEARCH METHODS}

In this research, the Statistical Package for the Social Sciences (SPSS) was used for data entry, as well as for examining the data later. Data preparation was the initial step, which aimed to convert raw data into a more structured format, which is more appropriate for analysis. Tasks in this stage included data editing, data coding and data entry. Descriptive statistics were used to summarize respondent's characteristics, including demographic information, such as age, gender; also, questions.

Furthermore, inferential statistics were used to test hypotheses to determine the relationship between variables. In particular, Pearson correlation was used to verify the association of interval level to the construct, whilst chi-square was used to validate the association between nominal variables and the construct. Moreover, the Cronbach alpha coefficient was used for reliability tests. Lastly, the variable analysis tool, analysis of variance (ANOVA), was used to determine relationship between environmental accounting as perspective for hotels of Aqaba Special Economic Zone Authority (ASEZA).

\subsection{Hypotheses}

The research model with five hypotheses is presented in Figure 1.

H1: The Jordanian legislative system contributes to the implementation of environmental accounting in Aqaba Special Economic Zone.
H2: The level of awareness among the hotels of Aqaba Special Economic Zone doesn't help in implementing environmental accounting.

H3: Hotel-related factors (location, capital, turnover, the kind of business that the hotel performs) don't help in implementing environmental accounting.

H4: The level of incentives given to the hotels of Aqaba Special Economic Zone doesn't help in the implementation of environmental accounting.

H5: There is no relationship between the implementation of environmental accounting and the availability of qualified human resource.

\subsection{Study population}

To achieve the objectives of the study, and gauge the possibility of implementing environmental accounting in Aqaba Special Economic Zone, the study population is going to be the classified and rated hotels of the Aqaba Special Economic Zone, which is 33 hotels in total.

\subsection{Study tools}

To study the possibility of applying environmental accounting in the hotels of Aqaba Special Economic Zone, this study will basically focus on two tools gather data and information required for achieving the objectives of the study, these are as follows for gathering the:

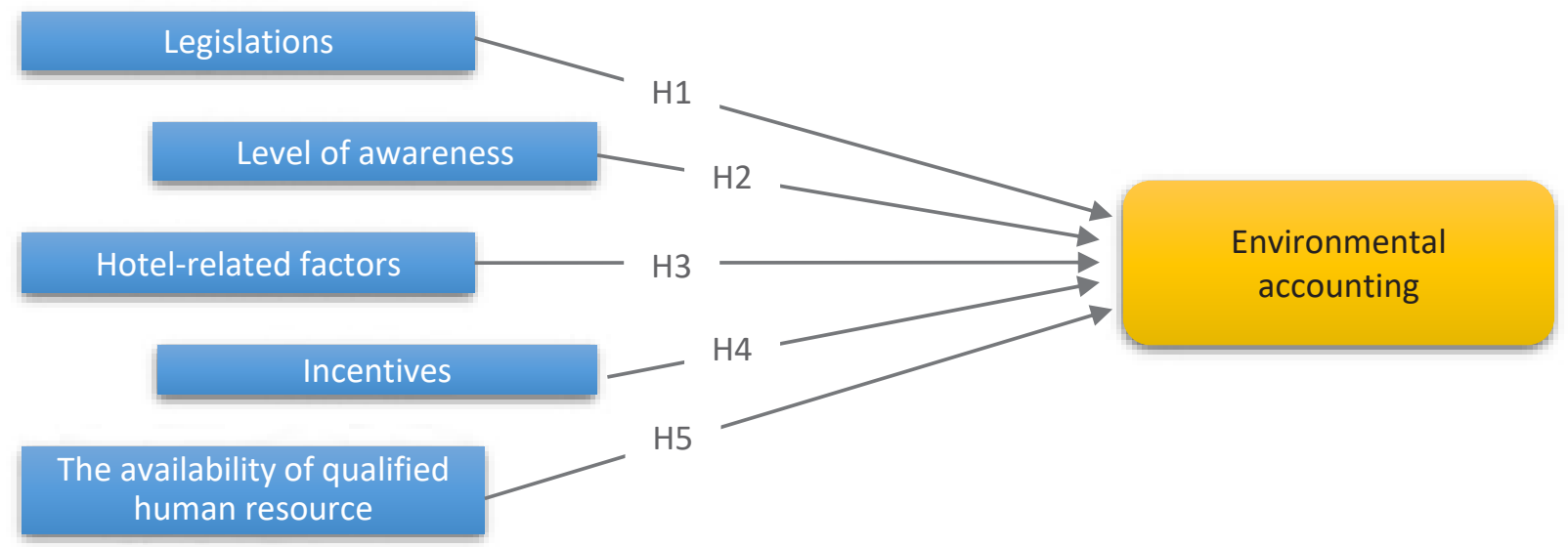

Figure 1. Research model 
1. The financial reports published by the investment department of Aqaba, wherefrom the information regarding the hotels is acquired (size of the financial assets, production size, gross capital, geographical location of the hotel, nature of their business), and the legislation and international standards of environmental accounting.

2. The questionnaire, which was tailor made according to its literature and it consists of three parts:

- part one: contains personal information regarding the respondent (gender, age, educational qualification, field of specialization, and years of experience);

- part two: contains questions, which gauge the possibility of implementing environmental accounting in the hotels of Aqaba Special Economic Zone, and these questions were further divided into the following groups and dimensions: legislations regarding the implementation of environmental accounting, companies managements' awareness about the importance of environmental accounting, factors related to the hotels (size of the financial assets, production size, gross capital, geographical location of the hotel, nature of their business), incentives provided to the hotels for implementing environmental accounting, qualifications of the human resource and the major suggestion that would help in implementing environmental accounting;

- part three: contains an open-ended question regarding the factors that could contribute to implementing environmental accounting.

3. Legislations have been measured using an eight-point scale (1-8).

4. Companies managements' level of awareness has been measured using 14 different clauses (9-22).

5. Factors related to hotels (size of the financial assets, production size, gross capital, the geographical location of the hotel, nature of their business) were measured using 6 clauses (23-28).
6. Incentives provided to the hotels were measured using 9 clauses (29-37).

7. Qualifications of the human resource were measured using 6 clauses (38-43).

Based on this, the study population consists of the environment of the classified and rated hotels of Aqaba Special Economic Zone. The number of questionnaires distributed was 150 , of which 120 were returned and they were all viable for statistical analysis.

\subsection{Authenticity and reliability of this study}

1. This measures the reliability of the tools used to analyze the different variables of this study, and the results of this analysis would be considered acceptable if their Cronbach alpha value $(75.4 \%)$ is greater than $60 \%$ (Sekaran, 1992) and as the value raises closer to $100 \%$, this study tool is considered more reliable, and by looking at data in Table 1, we find that the alpha value ranges between 0.623 and 0.848 , thus, the tools of this study can be considered stable, and the data generated through these study tools are considered reliable for measuring the variables, and that they have a high degree of probability.

Table 1. Authenticity and reliability of this study

\begin{tabular}{l|c}
\hline \multicolumn{1}{c|}{ Variable } & Cronbach alpha value \\
\hline Legislations & $68.7 \%$ \\
Companies managements & \\
awareness & $84.6 \%$ \\
\hline Incentive system & $83 \%$ \\
\hline Hotel-related factors & $84.8 \%$ \\
\hline Level of incentives & $72.5 \%$ \\
\hline Total & $75.4 \%$ \\
\hline
\end{tabular}

Results related to the sample respondents answers.

Table 2. Frequency distribution of the study sample according to their age

\begin{tabular}{l|c|c}
\hline \multicolumn{1}{c|}{ Age } & $\begin{array}{c}\text { Number } \\
\text { of employees }\end{array}$ & Percentage \\
\hline 25 or younger & 27 & 22.5 \\
\hline 25 to younger than 35 & 22.5 & 27 \\
\hline 35 to younger than 45 & 20 & 16.7 \\
\hline 45 to younger than 55 & 46 & 38.3 \\
\hline 55 or more & 0 & 0 \\
\hdashline Total & 120 & 100 \\
\hline
\end{tabular}


It's clear from Table 2 that a large number of the respondents were older than 51 years, to be exact, they made up $38.3 \%$ of the study sample, 31 to 40 years old were $22.5 \%$ as was the percentage of those who were younger than 30 years old and 41-51 years made up the smallest percentage, which indicates that the majority of the respondents were more 50 years and this is only natural, as most of top managerial positions in the hotels of Aqaba Special Economic Zone belong to people from this age group.

Table 3. Frequency distribution of the study sample according to their gender

\begin{tabular}{l|c|c}
\hline \multicolumn{1}{c|}{ Gender } & $\begin{array}{c}\text { Number } \\
\text { of respondents }\end{array}$ & Percentage \\
\hline Male & 66 & 55 \\
\hdashline Female & 54 & 45 \\
\hdashline Total & 120 & 100 \\
\hline
\end{tabular}

It's clear from Table 3 that $55 \%$ of the respondents were male, on the other hand, $45 \%$ of the respondents were female, and this clearly shows that females hold a quite healthy percentage of the managerial jobs in the hotels of Aqaba Special Economic Zone.

Table 4. Frequency distribution of the study sample according to their educational qualification

\begin{tabular}{l|c|c}
\hline $\begin{array}{c}\text { Level } \\
\text { of education }\end{array}$ & $\begin{array}{c}\text { Number of } \\
\text { employees }\end{array}$ & Percentage \\
\hline PhD & 1 & 0.8 \\
\hline Master & 37 & 30.8 \\
\hline Higher diploma & 39 & 32.5 \\
\hline Bachelor & 27 & 22.5 \\
\hline Diploma & 16 & 13.3 \\
\hline Total & 120 & 100 \\
\hline
\end{tabular}

It's clear from Table 4 that the majority of the respondents have a higher diploma, as they consist $30.8 \%$ of the total respondents and this clearly shows that most of the top managerial positions are held by well qualified managers, and among them there are $(30.8 \%)$ who have master degree, $22.5 \%$ who have bachelor degree, $13.3 \%$ who have diploma and only one of the respondents had a $\mathrm{PhD}$ degree, which is equal to $0.8 \%$.
Table 5. Frequency distribution of the study sample according to their experience

\begin{tabular}{l|c|c}
\hline $\begin{array}{c}\text { Years } \\
\text { of experience }\end{array}$ & $\begin{array}{c}\text { Number } \\
\text { of employees }\end{array}$ & Percentage \\
\hline Less than 5 years & 40 & 33.3 \\
\hline $5-10$ & 54 & 45 \\
$11-15$ & 16 & 13.3 \\
\hline $16-20$ & 7 & 5.8 \\
\hline $21-25$ & 2 & 1.6 \\
\hline More than 25 years & 1 & 0.83 \\
\hline Total & 120 & 100 \\
\hline
\end{tabular}

It's clear from Table 5 that a substantial number of respondents belong to the 6-10 years experience group with a percentage of $45 \%$, they are followed by those with less than 5 years experience with a percentage of $33.3 \%$, which is also a high percentage compared to other experience groups, then come the respondents with 11-15 years of experience with a percentage of $13.3 \%$, they are followed by respondents with 16-20 years of experience with 5.8\%, 21-25 make up 1.6\% of the respondents and finally only one respondent had more than 25 years of experience and he made up $0.83 \%$ of the respondents.

H1: The Jordanian legislative system contributes to the implementation of environmental accounting in Aqaba Special Economic Zone.

Testing of the first hypothesis is presented in Table 6 .

Table 6. $T$-test alpha value test Jordanian legislative system

\begin{tabular}{c|c|c:c:c}
\hline $\begin{array}{c}\text { SUM } \\
\text { of squares }\end{array}$ & Df & $\begin{array}{c}\text { Mean } \\
\text { square }\end{array}$ & $\boldsymbol{t}$ & Sig \\
\hline 15.174 & 3 & 5.058 & 61.898 & 0.000 \\
\hline
\end{tabular}

It's clear from Table 6, that $t$-value is (61.898) and the value of indexed $t$ is 47.47 at the designated Alpha value 0.000 , which is less than 0.05 , which means that we refute the nihilist hypothesis "The Jordanian legislative system doesn't contribute to the implementation of environmental accounting in Aqaba Special Economic Zone". And we accept the alternative hypothesis $H 1$ and it is: "The Jordanian legislative system contributes to the implementation of environmental accounting in Aqaba Special Economic Zone".

H2: The level of awareness among the hotels of Aqaba Special Economic Zone doesn't help in implementing environmental accounting. 
Testing of the second hypothesis is presented in Table 7, which shows the $t$-value of the second hypothesis "The level of awareness among the hotels of Aqaba Special Economic Zone doesn't help in implementing environmental accounting".

Table 7. $T$-value and the level of awareness among the hotels

\begin{tabular}{c|c|c|c|c}
\hline $\begin{array}{c}\text { SUM } \\
\text { of squares }\end{array}$ & Df & $\begin{array}{c}\text { Mean } \\
\text { square }\end{array}$ & $\boldsymbol{t}$ & Sig \\
\hline 11.239 & 1 & 11.239 & 138.797 & 0.000 \\
\hline
\end{tabular}

H3: Hotel-related factors (location, capital, turnover, the kind of business that the hotel performs) do help in implementing environmental accounting.

Testing of the third hypothesis is presented in Table 8 and proved by the variance analysis.

Table 8. $T$-test and alpha value test of hotelrelated factors

\begin{tabular}{c|c|c|c|c}
\hline $\begin{array}{c}\text { SUM } \\
\text { of squares }\end{array}$ & Df & $\begin{array}{c}\text { Mean } \\
\text { square }\end{array}$ & $\boldsymbol{t}$ & Sig \\
\hline 11.239 & 1 & 11.239 & 138.797 & 0.000 \\
\hline
\end{tabular}

In Table $8, t$-value is 138.797 and the value of indexed $t$ is 47.47 for the variable of hotel-related factors at the designated alpha value 0.000 , which is less than 0.05 , which means that we refute the nihilist hypothesis "hotel-related factors such as location, capital, turnover, the kind of business that the hotel performs, its proximity to residential areas do contribute to the implementation of environmental accounting" and accept the alternative hypothesis $\mathrm{H1}$ : "Hotel-related factors such as location, capital, turnover, the kind of business that the hotel performs, its proximity to residential areas contribute to the implementation of environmental accounting".

H4: The level of incentives given to the hotels in Aqaba Special Economic Zone doesn't help in the implementation of environmental accounting.

Testing of the fourth hypothesis is presented in Table 9.
Table 9. Variance analysis, $t$-test for the forth hypothesis

\begin{tabular}{c|c|c|c|c}
\hline $\begin{array}{c}\text { SUM } \\
\text { of squares }\end{array}$ & Df & $\begin{array}{c}\text { Mean } \\
\text { square }\end{array}$ & $\boldsymbol{t}$ & Sig \\
\hline 6.785 & 1 & 1 & 48.965 & 0.000 \\
\hline
\end{tabular}

It's clear from Table 9 that $t$-value is 48.965 and the value of indexed $t$ is 47.47 for the variable of incentive related factors at the designated alpha value 0.000 , which is less than (0.05), which means that we refute the nihilist hypothesis $\mathrm{HO}$ that assumes: "The level of incentives given to the hotels in Aqaba Special Economic Zone doesn't help in the implementation of environmental accounting" and accept the alternative hypothesis H1: "The level of incentives given to the hotels in Aqaba Special Economic Zone helps in the implementation of environmental accounting".

H5: There is no relationship between the implementation of environmental accounting and the availability of qualified human resource.

Testing of the fifth hypothesis is presented in Table 10 , which shows the $t$-test for the fifth hypothesis by the variance analysis.

Table 10. Variance analysis, $t$-test for relationship between the implementation of environmental accounting and the availability of qualified human resource

\begin{tabular}{c|c|c|c|c}
$\begin{array}{c}\text { SUM } \\
\text { of squares }\end{array}$ & Df & $\begin{array}{c}\text { Mean } \\
\text { square }\end{array}$ & $\boldsymbol{t}$ & Sig \\
\hline 19.074 & 3 & 6.358 & 62.815 & 0.000 \\
\hline
\end{tabular}

It's clear from Table 10 that $t$-value is 62.815 and the value of indexed $t$ is 47.47 for the variable of qualified human resource factor at the designated alpha value 0.000 , which is less than 0.05 , which means that we refute the nihilist hypothesis $\mathrm{HO}$ that assumes: "There is no relationship between the implementation of environmental accounting and the availability of qualified human resource" and accept the alternative hypothesis H1: "There is a relationship between the implementation of environmental accounting and the availability of qualified human resource". 


\section{The mean and the standard deviation}

The researchers have calculated the mean and the standard deviation for the sum of the factors of human resource and they are represented in Table 11.

Table 11. The mean and the standard deviation

\begin{tabular}{|c|c|c|c|}
\hline No & Paragraphs of resolution & $\begin{array}{l}\text { Standard } \\
\text { deviation }\end{array}$ & Average \\
\hline \multicolumn{4}{|c|}{ Legislations } \\
\hline 1 & $\begin{array}{l}\text { The Jordanian legislations don't make obligatory on hotels to implement the procedures of } \\
\text { environmental accounting }\end{array}$ & .749 & 3.708 \\
\hline 2 & Advancements in environmental legislations help in implementing environmental accounting & .616 & 4.083 \\
\hline 3 & Not implementing environmental accounting results in fines and penalties against the hotels & .791 & 4.191 \\
\hline 4 & $\begin{array}{l}\text { The Jordanian legislations make it obligatory to abide by the accounting standards when it comes } \\
\text { to implementing environmental accounting }\end{array}$ & .549 & 4.033 \\
\hline 5 & $\begin{array}{l}\text { The absences of a regulatory body, which monitors the implementation of environmental } \\
\text { accounting, affected its implementation negatively }\end{array}$ & .325 & 3.94 \\
\hline 6 & $\begin{array}{l}\text { The legislations don't allow governmental bodies to accept or attest the financial statements of } \\
\text { companies, which are implementing environmental accounting }\end{array}$ & .454 & 3.808 \\
\hline 7 & $\begin{array}{l}\text { Do the hotels of Aqaba Special Economic Zone consider the article (4) issued by the Ministry of } \\
\text { Securities, which stated that the contribution made to environmental accounting by hotels should } \\
\text { be made public to national and international communities }\end{array}$ & .738 & 3.550 \\
\hline 8 & $\begin{array}{l}\text { Are there any legal actions taken against the hotels in Aqaba Special Economic Zone, which } \\
\text { refuse to implement article (4) issued by the Ministry of Securities, which stated that the } \\
\text { contribution made to environmental accounting by hotels should be made public to national and } \\
\text { international communities }\end{array}$ & .333 & 4.333 \\
\hline \multicolumn{4}{|c|}{ Level of awareness } \\
\hline 9 & The procedure of environmental accounting is an implementable idea & 2.805 & 4.400 \\
\hline 10 & Management of hotels has a clear understanding of the concept of environmental accounting & .8178 & 3.558 \\
\hline 11 & $\begin{array}{l}\text { There is a need for implementing environmental accounting in the hotels of Aqaba Special } \\
\text { Economic Zone }\end{array}$ & 6384 & 3.750 \\
\hline 12 & $\begin{array}{l}\text { Implementing the procedures of environmental accounting help gaining from environmental } \\
\text { revenues, which result from the selling of environmental waste }\end{array}$ & .5334 & 4.533 \\
\hline 13 & Implementing environmental accounting help in improving the decision making process & .7991 & 4.0000 \\
\hline 14 & $\begin{array}{l}\text { Stating the amount spent by hotels on environmental accounting help in increasing its business } \\
\text { and room occupancy }\end{array}$ & .6468 & 3.791 \\
\hline 15 & $\begin{array}{l}\text { Implementing environmental accounting help in reducing pollution by creating awareness about } \\
\text { disposal of contaminated waste }\end{array}$ & .945 & 3.95 \\
\hline 16 & $\begin{array}{l}\text { Implementing environmental accounting and disclosing facts about it can hurt the reputation of } \\
\text { the hotel }\end{array}$ & 1.119 & 3.90 \\
\hline 17 & $\begin{array}{l}\text { The accountant should not be restricted to making financial statements and his tasks should also } \\
\text { include environmental accounting }\end{array}$ & 1.00 & 3.50 \\
\hline 18 & Implementing environmental accounting adds an unnecessary cost to the operation of the hotel & 1.005 & 3.20 \\
\hline 19 & $\begin{array}{l}\text { I support that the hotel should lodge an accounting complaint against the hazardous } \\
\text { environmental activities of its production facilities }\end{array}$ & .470 & 4.30 \\
\hline 20 & $\begin{array}{l}\text { Implementing environmental accounting helps in reducing pollution by overtly declaring the } \\
\text { expenditures made on containing pollution }\end{array}$ & 1.081 & 2.70 \\
\hline 21 & Implementing environmental accounting in a hotel makes its financial statements more accurate & .845 & 2.50 \\
\hline 22 & Environmental accounting helps in making financial decisions & 1.13 & 4.15 \\
\hline \multicolumn{4}{|c|}{$\begin{array}{r}\text { Hotel-related factors } \\
\end{array}$} \\
\hline 23 & The size of the financial assets hinders the implementation of environmental accounting & .8074 & 4.3583 \\
\hline 24 & The scale of the business hinders the implementation of environmental accounting & .6331 & 3.950 \\
\hline 25 & The size of the capital hinders the implementation of environmental accounting & .5797 & 4.241 \\
\hline 26 & $\begin{array}{l}\text { The proximity of the hotel to residential areas hinders the Implementation of environmental } \\
\text { accounting }\end{array}$ & .8205 & 3.625 \\
\hline 27 & $\begin{array}{l}\text { Implementing environmental accounting in the hotels of Aqaba Special Economic Zone prolongs } \\
\text { the business cycle of the hotel }\end{array}$ & .6520 & 3.808 \\
\hline 28 & $\begin{array}{l}\text { The kind hospitality services that the hotels render affect the Implementation of environmental } \\
\text { accounting }\end{array}$ & 1.051 & 3.766 \\
\hline
\end{tabular}


Table 11 (cont.). The mean and the standard deviation

\begin{tabular}{|c|c|c|c|}
\hline No & Paragraphs of resolution & $\begin{array}{l}\text { Standard } \\
\text { deviation }\end{array}$ & Average \\
\hline \multicolumn{4}{|c|}{ Incentives } \\
\hline 29 & There is a custom concession on production technologies, which are eco-friendly & .8886 & 3.516 \\
\hline 30 & $\begin{array}{l}\text { Custom concessions on eco-friendly technologies make them appear as social assets, which help } \\
\text { in implementing environmental accounting }\end{array}$ & .9074 & 3.841 \\
\hline 31 & There is a tax concession for hotels on production technologies, which are eco-friendly & 1.070 & 3.616 \\
\hline 32 & $\begin{array}{l}\text { Giving hotels tax concessions if they keep social assets helps in implementing environmental } \\
\text { accounting }\end{array}$ & 1.197 & 3.391 \\
\hline 33 & $\begin{array}{l}\text { There are concessions on social assets and machines, which don't help in implementing } \\
\text { environmental accounting }\end{array}$ & 1.216 & 3.000 \\
\hline 34 & Making eco-friendly investments by investors help in implementing of environmental accounting & .7884 & 2.816 \\
\hline 35 & Releasing the social assets publically helps in improving its public image & .7849 & 3.825 \\
\hline 36 & $\begin{array}{l}\text { There is governmental support which helps hotels in acquiring social assets and that } \\
\text { consequently helps in implementing environmental accounting }\end{array}$ & 1.046 & 3.116 \\
\hline 37 & $\begin{array}{l}\text { Hotels which keep social assets are given priority when tendering and that helps in implementing } \\
\text { environmental accounting }\end{array}$ & .8215 & 3.675 \\
\hline \multicolumn{4}{|c|}{ The availability of qualified human resource } \\
\hline 38 & $\begin{array}{l}\text { The lack of awareness and implementation about the new trends in accounting discourage the } \\
\text { implementation of environmental accounting }\end{array}$ & .7491 & 3.708 \\
\hline 39 & Having no training units discourage the implementation of environmental accounting & .6160 & 4.083 \\
\hline 40 & $\begin{array}{l}\text { Holding special courses in environmental accounting helps in implementing environmental } \\
\text { accounting }\end{array}$ & .7917 & 4.191 \\
\hline 41 & $\begin{array}{l}\text { There is a lack of knowledge about environmental accounting among the personnel of the } \\
\text { financial department }\end{array}$ & .7491 & 3.708 \\
\hline 42 & $\begin{array}{l}\text { It's rare to find well qualified personnel in the fields of management and finance who are also } \\
\text { qualified in the field of environmental accounting }\end{array}$ & .6160 & 4.083 \\
\hline 43 & The personnel in the financial department lack skill to work on environmental accounting & .7917 & 4.1917 \\
\hline
\end{tabular}

From the data in Table 11, we find that the responses of the respondents are positive and it is because the response mean is bigger than the mean of the study tool (3), which shows the degree of agree- ment fall in the upper segment (5-3.51) and the standard deviation ranges between 4.5333 and 4.4000 , and this can be seen in the "mean" and "standard deviation" column of Table 11.

\section{CONCLUSION}

Hotels in Aqaba Special Economic Zone face difficulties and obstacles in the implementation of environmental accounting because of factors related to legislation, level of awareness about environmental accounting, factors related to the hotels and the qualification of human resource.

In the legislation related to environmental accounting, the biggest obstacles were: no legislations were passed for making the implementation of environmental accounting obligatory; legislations don't make it obligatory for hotels to make eco-friendly investments and the absence of a governmental body that makes it obligatory for hotels to release their financial accounts to the public. But there is European accounting legislation in order to require large companies with more than 500 employees to provide additional information on social and environmental matters (Beredugo \& Mefor, 2012; Hsieh \& Jeon, 2010).

The most important thing that was done in the Hashemite Kingdom of Jordan was the establishment of the Environmental Police Department in 2006 with the aim of controlling and limiting environmental violations. The Environmental Police Department is the executive tool of the Ministry of the Environment in Jordan, it is the first of its kind in Arab world. To give it more legal authority, its name has been changed to be Royal Department for Protecting Environment (Al Dosaree, 2011). It is concluded that companies comply with the environmental accounting legislation issued by those countries in which these companies operate. These companies behave like this on order to avoid falling into prob- 
lems and obligations that may result in compensation in various forms for the employees of these companies (Moussa, 2012). We stress the need to establish environmental accounting standards to enhance the role of environmental accounting legislation. Several studies have addressed the impact of legislations on the application of environmental accounting. Many studies have concluded that legislations exist but the main problem lies in the application of the legislations (Moussa Saleh, 2007; Al Dosaree, 2011).

It can be said that the most prominent environmental legislation and laws in Jordan for industrial organizations include the following.

Every facility that carries out an activity that adversely affects the environment should prepare a study to assess the environmental impact of its projects to make an appropriate decision by the Ministry of the Environment. Issuance of legislations for accounting standards, standards for publicly releasing financial statements, making it obligatory for the hotels in Aqaba Special Economic Zone to implement environmental accounting, enforces penalties on hotels that don't abide by these rules, as these hotels would be monitored by onsite inspection and inspection of their accounting and financial records by the specialized team from Ministries of the Environment and organizations and third party editors who edit the accounts of these hotels.

Amending the tax and customs laws so as they allow a special exemption for social assets that are eco-friendly will encourage the usage of such technologies.

Organizations that engage in activities that negatively affect the environment and emit environmental pollutants must install devices to prevent the spread of contaminants and control those pollutants to be within the permissible limits according to the approved specifications.

Item (4) of Article 21 of Instructions of Issuing Companies Disclosure, Accounting and Auditing Standards 2004 states that the report of the Company's Board of Directors shall include disclosure of the company's contribution to environmental protection and community service.

As a result of the importance of accounting legislation and standards in the application of environmental accounting disclosure, Eljayash (2015) attempted to highlight the strength of legal and regulatory restrictions that focus on environmental disclosure in the country in which the company is located and noted the importance of complying with the accounting standard relating to environmental accounting disclosure. Companies resident in countries that comply with environmental disclosure systems are more concerned with environmental issues, and therefore country-specific legislation significantly affects compliance with accounting standards. Therefore, we may find that there is a requirement by some standards and legislation for companies to disclose environmental accounting, but this disclosure may be limited to certain items that are almost in the form of an enumeration of some unnecessary information.

The biggest difficulties related to the level of awareness about environmental accounting consist of: issuing the financial statements doesn't improve the turnover of hotels, releasing of the social assets of hotels doesn't improve its public image, hotel management doesn't have a clear understanding of the environmental accounting concept, the hotel management doesn't know the significance of implementing environmental accounting and it is clearly visible in their response that the cost of implementing environmental accounting exceeds its benefits and that it's an unnecessary cost and the hotel management believes the current system is sufficient enough and there is no need for the implementation of environmental accounting. However, in order to raise awareness about environmental issues, it is necessary for hotel management to make decisions on the implementation of environmental protection activities.

The study of Hanan (2014), Saleh (2015), Al Dosaree (2011) attempted to identify the extent to which corporate management recognized the importance of environmental accounting and environmental 
accounting disclosure, and the role of this awareness in the application of environmental accounting. Environmental and Environmental Accounting Disclosure. Saleh (2015) concluded that there is no accounting system that meets the purposes of accounting measurement and disclosure of environmental performance.

The study of Al-Taher (2010), Saleh (2015) recommended increasing the environmental awareness of the public and the users of the financial statements in response to the increasing pressures exerted by government bodies and agencies through environmental legislation and regulations.

Babaker study (2014) also found that senior management is convinced that the measurement and fair disclosure of environmental costs contributes to the quality of the financial statements, as well as it is concerned with the awareness of employees in areas of environmental responsibility. However, there is weakness in the regulatory bodies and public bodies on the environmental performance of companies.

Environmental performance indicators and environmental costs make a set of environmental information, which explains the level of hotel environmental awareness.

The obstacles that environmental accounting faces regarding the qualified human resource consist of the following: the lack of knowledge about the current developments in the field of environmental accounting, absence of training units, the number of employees in the financial departments is not sufficient, there are no environmental accounting experts in the universities that can help in its implementation.

Environmental accounting disclosure is different from one country to another depending on the legal and economic system applicable in that country (Eljayash, 2015). The application of the environmental accounting disclosure system varies according to the factors surrounding the facility itself. The application of environmental accounting disclosure is influenced by the social development surrounding the entity and the size of the entity is an important factor in the application of accounting disclosure.

The application of environmental accounting is influenced by factors related to the company. The size of the company's assets, the size of its production, the size of its capital, the geographical location and the nature of the activity all affect the application of environmental accounting. The application of environmental accounting is related to the age of production. The application of environmental accounting is greatly influenced by the type of activity of the establishment.

Encouraging companies to apply environmental accounting disclosure through the enactment of laws commensurate with supporting the applicable companies as well as imposing fines on companies that violate or do not apply environmental disclosure requirements.

The study also recommended the need to develop environmental awareness among the members of society by urging them to deal with companies that preserve the environment and to move towards environmentally-friendly industries. The Central Bank should also provide instructions to commercial banks, including: demand from Jordanian industrial companies when they apply for financing (loans), a clearance from the Ministry of the Environment stating that the company has not registered any environmental violations against it.

Lulu (2016) conducted a number of questions in order to identify the availability of qualified personnel within the organization, which can apply the environmental accounting in the required form. Some questions were asked directly whether qualified human resources are available, which can measure environmental costs and whether the administration of the organization develops and pays attention to these competencies, and the availability of training plans that enable the employees of the organization to measure the environmental costs correctly. 
The results of this study indicate that the level of training of human resources in the fields of the environment, in the industrial companies in Gaza, does not rise to the required level and therefore does not help in the application of environmental accounting. There are also no training plans linked to the environmental objectives to be achieved. One of the main recommendations of the study was the need to create specialized training courses to qualify employees to do what is required within the framework of environmental accounting.

The IT (information technology) related difficulties could be summed up as follows: the lack of clear understanding and awareness about environmental accounting and there are no efforts to create awareness about its benefits, the lack of clear concept regarding environmental editing and the absence of accounting systems that suits the requirements of environmental accounting and the difficulty of determining the environmental cost and revenue.

The implementation of environmental accounting in the hotels in Aqaba Special Economic Zone is greatly affected by the hotel-related factors such as location, capital, turnover, the kind of business that the hotel performs, its proximity to residential areas, and the implementation of environmental accounting directly affect the business cycle of the hotel.

The obstacles faced by the hotels of Aqaba Special Economic Zone vary depending on the factors related to the hotels such as size of turnover, capital, proximity to residential areas and the nature of its operations.

The implementation of environmental accounting enables environmental organizations to gauge the efforts made by the hotels of Aqaba Special Economic Zone to reduce pollution, as implementing environmental accounting will make it obligatory for the hotels to publicly release their environmental expenditures, this will make it easier to track and explain the eco-friendly activities of the hotel, and such expenditures could include: waste disposal, and this makes it obligatory for the hotels to reduce pollution when is publicly issuing such statements, and here we want to highlight the importance of recording such costs by the accountants.

The factors that require an environmental accounting system also require an environmental accounting system on the same information, so that the environmental accounting system in Aqaba Special Economic Zone can be a comprehensive one.

The issue of environmental accounting should get its due importance, and there should be an academic branch that students can specialize in.

Academic researches on the topic of environmental accounting should be encouraged.

And among other things that can help in the implementation of environmental accounting, the study shows the following:

1. The necessity of making custom exemptions on eco friendly technologies and equipments for the hotels.

2. Development of accounting methods which are compatible with environmental accounting.

3. The role of the accounting should not only be restricted on making financial accounts but it should also include making of environmental accounts.

4. The Jordanian universities should teach a course on environmental accounting. 
5. Hotels should lodge an accounting report about the environmental effects of their operations, and that is through making of financial statements that disclose information regarding environmental accounting.

\section{RECOMMENDATIONS}

Making researches on environmental accounting standards so that they can be adapted to the Jordanian environment. The financial accountant must do their part for the implementation of environmental accounting and that through activating environmental accounting, focusing on environmental accounting measures and ensuring how much transparency is implied in environmental accounting measures and how committed the hotel is to such measures.

\section{REFERENCES}

1. Aaheim, A., \& Nyborg, K. (1995). On the interpretation and applicability of a Green National Product. Review of Income and Wealth, 41(1), 57-71. https://doi. org/10.1111/j.1475-4991.1995. tb00093.x

2. Abdel Aziz, Jafar, O., \& Al-Sharif (2016). The Obligation of Industrial Companies to Disclose the Costs of Social Responsibility. Journal of Economic Sciences, 17(1), 106-121.

3. Abu Rumman, M., Jawabreh.O, Alhyasat, K, \& Husam, H. (2013). The Impact of Work Environment on the Average of Job Turnover in Five-Star Hotels in Al-Aqaba City. Business Management and Strategy, 4(2). https://doi.org/10.5296/bms. v4i 2.4020

4. Al Dosaree, M. (2011). The Importance of Accounting for Environmental Costs in Improving the Quality of Accounting Information (A Field Study on Industrial Companies Listed on the Kuwait Stock Exchange) (Unpublished Master Thesis, Middle East University, Amman).

5. Al Taher, A. (2010). Effect of Environmental Costs on Evaluation of the Performance of Sudanese Industrial Establishments (Applied Analytical Study on the Oil Sector) (Research Proposal for Master Degree, Red Sea University, Sudan).

6. AL-Ashqar, A. (2011). The Role of Administrative Accounting in Improving the Environmental Performance of Egyptian Business
Organizations (Applied Study) (Unpublished Master Thesis, Suez Canal University. Egypt).

7. AL-Farah, A, \& Riyad, H. (2011). The Disclosure of the Elements of Corporate Social Responsibility (CSR), A Case Study of Industrial Companies listed on the Amman Stock Exchange for 2007-2008. Jordan Journal of Business Administration, 7, 273-294.

8. Al-Hayek, K. (2013). Internal Environmental Auditing in the Jordanian Industrial Corporations Company (A Field Study). Dirasat Journal, Administrative Sciences, $40(2)$.

9. Alsarayreh, M. N., Jawabreh, O., Jaradat, M., \& Alamro, S. A. (2011). Technological impacts on effectiveness of accounting information systems (AIS) applied by Aqaba tourist hotels. European Journal of Scientific Research, 58(3), 361-369. Retrieved from https://www.researchgate.net/ publication/292568077_Technological_impacts_on_effectiveness_of_accounting_information systems_AIS_applied_by_Aqaba_ tourist_hotels

10. Al-Sha’ar, O., Zalloum, I., \& Omar, N. (2014). The Effect of Accounting for Social Responsibility on the Financial Performance of Industrial Companies in Jordan Public Share. Dirasat Journal, Administrative Sciences, 41(2).

11. Al-Sharif, A. (2016). The extent to which industrial companies are committed to disclosing social responsibility costs (A field study). Journal of Economic Sciences, 17(1).

12. Al-thaher, Humaidan (2011). Accounting Disclosure on Environmental Performance in Al-Ahlia Cement Company in Libya (Survey Study), Damascus University. Journal of Economic and Legal Sciences, 27.

13. Al-Zaher, A. Hemidan (2011). Accounting disclosure of environmental performance at the cement national company of Libya (Expedition study). Damascus University. Journal of economical science and law, 27(1).

14. Anjali Vachhani (2014). Environment accounting and reporting. SaiQm Journal of Commerce \& Management, 1(2).

15. Babaker, H. (2014). The Effect of Accounting Measurement and Disclosure on Environmental Costs in the Quality of Financial Reports (A Field Study at Petrodar Petroleum Operations) (A Supplementary Study for a Master's Degree in Accounting and Finance, Al-Zaeem Al-Azhari University).

16. Bartelmus, P. L. P. (1992). Environmental accounting and statistics. Natural Resource Forum, 16(1), 77-84. https://doi. org/10.1111/j.1477-8947.1992. tb00552.x

17. Beredugo, S. B., \& Mefor, I. P. (2012). The Impact of Environmental accounting and Reporting on Sustainable Development 
in Nigeria. Research Journal of Finance and Accounting, 3(7), 55-63. Retrieved from https:// www.researchgate.net/publication/267844917_The_Impact_of Environmental_Accounting_and Reporting_on_Sustainable_Development_in_Nigeria

18. Boyce, G. (2000). Public discourse and decision making: Exploring possibilities for financial, social and environmental accounting. Accounting, Auditing \& Accountability Journal, 13(1), 27-64. http://dx.doi. org/10.1108/09513570010316135

19. Burgwal, D., \& Vieira, R. (2014). Environmental Disclosure Determinants in Dutch Listed Companies. Revista Contabilidade \& Financas, 25(64), 60-78. http://dx.doi.org/10.1590/S151970772014000100006

20. Burritt, R. (2005). Implementing Environmental Management Accounting: Status and Challenges. Eco-Efficiency in Industry and Science, 18(2), 123-141.

21. Burritt, R. L. (2004). Environmental management accounting: roadblocks on the way to the green and pleasant land. Business Strategy and the Environment, 13(1), 13-32. https://doi.org/10.1002/bse.379

22. Burritt, R. L., \& Chika Saka (2006). Environmental management accounting applications and ecoefficiency: case studies from Japan. Journal of Cleaner Production, 14(14), 1262-1275. https://doi. org/10.1016/j.jclepro.2005.08.012

23. Eljayash, Kamal (2015). Documentation of Environmental Disclosure Practices in the Oil Companies in the Countries of the Arab Spring - Some Evidences from Egypt, Libya and Tunisia. Journal of Economics, Business and Management, 3(10).

24. Gray, R. H. (2010). Social and Environmental Accounting (Vol. 4/ set, 1st ed.). SAGE.

25. Hamad, M. (2014). The Effect of Measuring and Disclosing Environmental Costs in Improving the Efficiency of Environmental Performance (Applied Study) (Unpublished Master Thesis, Damascus University).
26. Hanan, S. Siyaf (2014). Accounting Standard for Environmental Impact and Disclosure in Industrial Institutions (Case Study of Hama Bouziane-Constantine) (Unpublished Master Thesis, University of Constantine, Algeria).

27. Hanik, N. (2014). The Impact of Adopting Jordanian companies of Social Responsibility on Its Financial Performance An empirical study on the companies listed at Amman Stock Exchange (Unpublished Master Thesis, Middle East University, Jordan)

28. Hsieh, Y., \& Jeon, S. (2010). Hotel Companies' Environmental Awareness and Commitment: A review of their web pages (Paper 13). Paper presented at International CHRIE Conference. Retrieved from https://libres.uncg.edu/ir/uncg/ listing.aspx? $\mathrm{id}=9803$

29. Ignazio, M., \& Siniscalco, D. (Eds.) (1996). National Accounts and the Environment. Springer. Retrieved from https://www.springer.com/ us/book/9780792337416

30. Jumaa, Mohamed Ahmed (2017). The Impact of Jordanian Companies on Social Responsibility on Their Financial Performance, Applied Study on Companies Listed on the Amman Stock Exchange (Unpublished Master Thesis, Middle East University, Jordan).

31. Lima Ribeiro, V. P., \& Aibar-Guzman, Cristina (2010). Determinants of environmental accounting practices in local entities: evidence from Portugal. Social Responsibility Journal, 6(3), 404-419. https://doi. org/10.1108/17471111011064771

32. Lu, K., \& Abeysekera, I. (2014). Stakeholders' power, corporate characteristics, and social and environmental disclosure: evidence from China. Journal of Cleaner Production, 64, 426-436. Retrieved from https://www.sciencedirect. com/journal/journal-of-cleanerproduction

33. Lulu Y, Jamal (2016). The Availability of the Components of Environmental Cost Accounting in Industrial Companies in the Gaza Strip (Analytical Field Study) (Unpublished Master Thesis, Islamic University, Gaza).
34. Mathews, R. (2008). Personal reflections on a tale of two books: social and environmental accounting research in the past, present and future. Australasian Accounting Business and Finance Journal, 2(1), 4-14. Retrieved from https:// ro.uow.edu.au/aabfj/vol2/iss1/2/

35. Monteiro, Sónia Maria da Silva, \& Aibar, Guzmán, Beatriz (2010). The influence of the Portuguese environmental accounting standard on the environmental disclosures in the annual reports of large companies operating in Portugal: A first view (2002-2004). Management of Environmental Quality: An International Journal, 21(4), 414-435. https://doi. org/10.1108/14777831011049070

36. Mousa Saleh, Muneer, m. Jaradat, Mohammad, F. Jebreel (2012). Environmental Disclosure in Industrial Companies in Aqaba. Journal of Management Research, 4(3). http://dx.doi.org/10.5296/jmr. v4i3.1481

37. Moussa, S. (2007). Obstacles to the Application of Environmental Accounting in Jordanian Industrial Joint Stock Companies (from the Management and External Auditor) (Unpublished Master Thesis, Al-Bayt University, Jordan).

38. Noemi Rossi, Raffaele Trequattrini (2010). Environmental reporting and accountability in the Lazio Region between national guidelines and pilot experiences of local governments in Italy. Economia Aziendale Online, 1(3). Retrieved from http://riviste.paviauniversitypress.it/index.php/ea/issue/ view/51

39. Omar Abdalla Jawabreh, \& Ali M Alrabei (2012). The Impact of Accounting Information System in Planning, Controlling and Decision-Making Processes in Jodhpur Hotels. Asian Journal of Finance \& Accounting, 4(1). https://doi. org/10.5296/ajfa.v4i1.1435

40. Ribeiro, V., \& Monteiro, S. (2009). Empirical research review on environmental accounting: public sector versus private sector. Paper presented at 12th CIGAR Conference, Modena, Italy, May $28^{\text {th }}-29^{\text {th }}$. 
41. Ruíz, José María Páez, Sandubete (2001). The role of environmental accounting in organizational change. An exploration of Spanish companies. Accounting, Auditing \& Accountability Journal, 14(2), 213-239. https://doi. org/10.1108/09513570110389323

42. Saleh, M. Abdullah (2015).

Environmental Awareness and its Role in the Application of Environmental Accounting Disclosure in the Jordanian Industrial Compa- nies, Public Participation and its Impact on Investor Decisions in the Amman Financial Market (Unpublished Ph.D. Thesis, Al-Jinan University, Lebanon).

43. Salen, M. Mohammad (2015). The Impact of Accounting Disclosure Level in Published Financial Statements on the Repercussions of the Financial Crisis in the Jordanian Banking Sector "Field study on the Jordanian commercial Banks" (Unpublished Master Thesis, Al Yarmouk University, Jordan).
44. Sciulli, N. (2010). An Accounting Research Agenda in the Context of Climate Change. Drawing on the Australian Local Government Sector. International Review of Business Research, 6(5), 125-136.

45. Uno, K., Bartelmus, P. (Eds.) (1998). Environmental Accounting In Theory And Practice. Springer. Retrieved from https://www.springer.com/us/ book/9780792345596 